\title{
African American's Struggle for Equality and African American Literature
}

\section{MSc Ivana Nakić Lučić}

University of Dubrovnik

Dubrovnik, Croatia

\section{Doi:10.5901/mjss.2013.v4n9p123}

\begin{abstract}
After the period of Reconstruction (1865-1877), the social position of Southern Negroes became worse. Negro leader Booker T. Washington, advocated gradual economic advancement of Negroes which was possible only if they relinquished their demand for political and civil rights. He believed that only self-reliant Negroes could more efficiently engage in the struggle for social equality. Other Negro leaders strongly opposed these tactics of gradual development. William E. B. Du Bois, historian and intellectual, was more radical in his ideas. He believed that Negroes must be united in their constant protest against discrimination in the white society and should insist on getting full political and civil rights immediately as well as the right to be educated according to economic circumstances and intellectual abilities. He highligted the advantage of higher education as only educated Negroes could set realistic goals for the Negro population and lead them in their struggle for social equality. Although Washington and his opponents had the same goal, their methods to achieve it differed. Washington strove to reach that goal indirectly, without creating white opposition. African-American literature depicts the reality discussed by politicians on the ideological level and transfers it into the spheres of intimate human drama giving it a moving quality and emotional recognizability. The principle of authenticity, one of the principles of poetic realism, requires an artistic and detailed analysis of reality which leads to the principle of criticism. The Negro author essentially becomes a critic of the reality he has used in his work.
\end{abstract}

Keywords: Political rights, civil rights, economic advancement, the U.S.A., southern Negroes, black leaders, discrimination in the white society, discriminatory laws, higher education, industrial education, organized protest.

\section{Introduction}

This paper analyses and compares the political programs of Booker Washington and William Du Bois for the complete affirmation of the black population in the USA. The aim of the author is to show which of the programs is more efficient at achieving the final goal, i. e., social equality in the American white society. During the period of 40 years after the beginning of Reconstruction ${ }^{1}$ (1865), the position of Southern Negroes worsens. The American government adopts the policy of "non-interference in the racial problem" in the American South and leaves the Negroes at the mercy of exslaveholders. From 1896 to 1900, "Jim Crow"2 laws depriving Negroes of the right to vote and discriminating them both in society and in all spheres of human activities are enforced throughout the South. Physical violence, lynching and killing Negroes become so common that they don't provoke any public reaction. The Negroes are actually enslaved again. Black leadership faces the problem of how to help Southern Negroes achieve their civil and political rights. This problem causes conflicts among black leaders some of whom advocate return to their homeland-Africa while others propose active resistance and protest against injustice as a way of achieving their rights. However, the majority of blacks believes they will obtain their rights gradually, in a peaceful and democratic way. At the beginning of the 20th century a most heated controversy raged between two most prominent black leaders, Booker Washington and William Du Bois. Although they had the same goal, to help Negroes achieve full civil and political rights, their political programs were quite different. Booker Washington advocated economic advancement first followed by gradual achievement of civil rights which was

\footnotetext{
1 "Jim Crow" law -In U.S. history, any of the laws that enforced racial segregation in the South between the end of the formal Reconstruction period in 1877 and the beginning of a strong civil rights movement in the 1950s. Jim Crow was the name of a minstrel routine (actually Jump Jim Crow) performed beginning in 1828 by its author, Thomas Dartmouth ("Daddy") Rice. The term came to be a derogatory epithet for blacks and a designation for their segregated life. (Woodward, 1974)

${ }^{2}$ The Compromise of 1877 was an unwritten, informal deal between the Republicans and Democrats of Congress to recognize the Republican president if the following actions took place: removal of all federal troops from the Southern states, appointment of at least one southern Democrat into Hayes's administration, construction of a second transcontinental railroad in the South, legislation enacted to help industrialize the South. (Norton et al., 2005)
} 
contrary to Du Bois's strategy of a radical political activity in the existing sociocultural and political circumstances. The paper also incorporates literary descriptions depicting the reality Washington and Du Bois were parts of and presenting the reactions to their controversy in literature.

\title{
2. "Atlanta Compromise"
}

Booker Washington in his Atlanta Exposition (1895) address urges whites to provide blacks with jobs and industrial education and in return, Southern Negroes will stop insisting on social equality. Taking into account the deteriorating position of Negroes in southern society resulting from The Compromise of $1877^{3}$ Washington tries to help Southern Negroes as much as possible under the circumstances so he advocates industrial education which will help them survive. In his opinion, blacks must believe in "paternal" Southern whites and accept the white supremacy. He highlights mutual dependence of blacks and whites while at the same time he says that they have to be separated in all public places (railways, city transport, theater, cinema...): "...In all things that are purely social we can be as separate as the fingers, yet one as the hand in all things essential to mutual progress..." (Washington, 1986, p. 221-222) Washington tries to dissuade blacks from political activity as he believes that due to their ignorance they are not competent to use this privilege. He is convinced that the blacks will obtain social equality gradually: hard work, thrift and their excellence in crafts will make them useful to the community which will finally acknowledge them as equals with full political and civil rights. His thesis is artistically presented in The Color Purple: the business success of the main character's (Celie) stepfather is based on his applying this strategy successfully.

\begin{abstract}
...Before I planted a seed, I made sure this one and that one knowed one seed out of three was planted for him. Before I ground a grain of wheat, the same thing. And when I opened up your daddy's old store in town, I bought me my own white boy to run it.... I bought him with whitefolks' money...(Walker, 1983, p. 155)
\end{abstract}

Washington delights the audience in Atlanta with his ideas on Negro progress which correspond to the general attitude of the whites at that time. He cunningly manipulates with the symbols and myths as "social darwinism" and "the gospel of wealth". With such submissive politics he gets huge financial support and a truly great power among the black population of the American South. Dominant, wealthy Northerners who invest money in the American South totally approve of Washington's politics of accommodation and his educational program. Southern whites agree with his politics as well as it advocates Negro inferiority and doesn't include any program aimed at getting political and civil rights for Negroes. His program is also accepted by white philantropists, some of whom are really interested in the Negro advancement while others are impressed by a practical program of educating "an inferior race" and creating a semiqualified working force which will be used in the future industry of the South and in agriculture.

African-American literature depicts the reality discussed by politicians on the ideological level and transfers it into the spheres of intimate human drama giving it a moving quality and emotional recognizability. The novel The Color Purple presents the problem of an enriched Negro who died because of the white majority that couldn't bear the advancement of a member of an inferior race.

\begin{abstract}
... Once upon a time, there was a well-to-do farmer who owned his own property near town. And as he did so well farming and everything he turned his hand to prospered, he decided to open a store, and try his luck selling dry goods as well. Well, his store did so well that he talked two of his brothers into helping him run it, and, as the months went by, they were doing better and better. Then the white merchants began to get together and complain that this store was taking all the black business away from them, and the man's blacksmith shop that he set up behind the store, was taking some of the white. This would not do. And so, one night, the man's store was burned down, his smithy destroyed, and the man and his two brothers dragged out of their homes in the middle of the night and hanged...(Walker, 1998, p. 148)
\end{abstract}

The black reality obviously offers a great number of similar examples thus the principle of authenticity, one of the principles of poetic realism, requires an artistic and detailed analysis of reality which leads to the principle of criticism. The Negro author essentially becomes a critic of the reality he has used in his work.

\footnotetext{
${ }^{3}$ Plessy v. Ferguson case in which, on May 18, 1896, the U.S. Supreme Court, advanced the controversial "separate but equal" doctrine for assessing the constitutionality of racial segregation laws. The Plessy v. Ferguson case was the first major inquiry into the meaning of the amendment's equal-protection clause. This ruling served as a controlling judicial precedent until its reversal in the case of Brown $\mathrm{v}$. Board of Education of Topeka (1954). (Norton et al., 2005)
} 


\title{
3. The Key of Success of Washington's Philosophy
}

Washington acted as an experienced politician and judged the situation in the American South well. He was convinced that a Negro insisting on social equality would be counter-efective. Washington was aware of the fact that at that time Negroes were completely unprepared and incapable of responsibly consuming their rights as well as fulfilling their duties resulting from the democratic constitution of American society. He claims that Negroes must start from the bottom, but he strongly believes that in the end they will achieve their goal:

\begin{abstract}
....t is important and right that all privileges of the law be ours, but it is vastly more important that we be prepared for the exercises of these privileges. The opportunity to earn a dollar in a factory just now is worth infinitely more than the opportunity than the opportunity to spend a dollar in an opera-house...(Washington, 1986, p. 223-224)
\end{abstract}

Using this clever parable Washington picturesquely presented his attitude on priorities for reaching full Negro emancipation and after that their integration. The fact which mustn't be disregarded is that if at the moment Negroes aren't equal to the whites it doesn't mean that in an ideal perspective they won't be socially and politically equal to the whites. Washington flattered both Northern and Southern whites for the crumbs from the good they had done for the black population. He also develops a strategy aimed at increasing financial and logistic support of the whites which will be used for the implementation of his program. At the same time his program becomes widely accepted by the growing Negro middle-class population. The emphasis on economic advancement which will indirectly solve the question of their civil and political rights, the interest for industrial education as well as advocating black pride and racial solidarity and denying any interest for social equality become the dominant ideas in the black community at that time.

It is really too difficult to deal with the burden of racial segregation particularly in the context of the search for identity, an essential phase in the development of human beings which can often be very painful, as French existentialist Jean Paul Sartre describes it. Together with denied identity a Negro constantly feels, it becomes logical why some black individuals strove to fit into the white community, which was very often tragicomical. Such an individual is Pauline, the black character from the novel The Bluest Eye, whom the girl from the white family she works for intimately calls Polly while her own daughter Pecola addresses her "Mrs Breedlove". One day Pecola and her friends visited her mother while she was working. Pecola liked the smell of the hot blueberry pie her mother had just made. The pan accidentally fell to the floor and the hot pie splattered Pecola. Instead of helping her Pauline "....was on Pecola, and with the back of her hand knocked her to the floor...slapped her again..." She said to her angrily: "...Crazy fool...my floor, mess...look what you....work...get on out...now that...crazy... my floor, my floor...my floor..." The frightened white girl started to cry and Pecola's mother comforted her as if she were her own child: "...Hush, baby,hush. Come here. Oh, Lord, look at your dress. Don't cry no more. Polly will change it..." The girl asked several times who the girls were and Polly replied: "...Don't worry none, baby..." (Morrison, 2007, p. 84-85) Pecola's mother herself projects the whites' hostily towards the blacks. It is her way of fitting into the white community. Her tragic misconception is a literary confirmation of both Washington's and Du Bois's attitude from the beginning of their political activity blaiming Negroes themselves for their subordinate position.

An extreme example of self-denial is Pecola's obsession with blue eyes. She longs for parental love and desires to be accepted by the community. The ugly black girl believes that blue eyes will earn her both her mother's love and friendship with her peers. She wants Soaphead Church to help her as he has a "supernatural power":

\footnotetext{
...Maybe you can do it for me...My eyes...I want them blue...Soaphead pursed his lips...it was at once the most fantastic and the most logical petition he had ever received. Here was an ugly little girl asking for beauty.... little black girl who wanted to rise up out of the pit of her blackness and see the world with blue eyes...For the first time he honestly wished he could work miracles... (Morrison, 2007, p. 137-138)
}

Such miracles cannot happen, but in a metaphorical and symbolic sense such a transformation corresponds to the most sublime human aspiration which is the inconquerable ideal of complete freedom of self-expression. It is an existential ideal requiring a perfectly just and a truly humane society for it to be fulfilled.

\section{Du Bois's Support of Washington's Philosophy}

In the late 1890s Booker Washington and William Du Bois on several occasions comment very similarly the ways and 
actions for the betterment of the Negro position. Namely, both leaders hold that economic advancement is more important than the right to vote. A certain level of knowledge and property, not race, must be a prerequisite for voting which must be applied to both blacks and whites equally. They firmly believe in black solidarity and economic cooperation within the black population as it is the only way to accumulate property and gradually advance in society. Both of them are convinced that it is crucial to civilize ignorant Southern Negroes, ensure their elementary and industrial education which will enable them to accumulate property and improve their position in American society. Although Du Bois agrees with Washington as to the education of the masses of Southern Negroes, he thinks it is crucial to open several Negro colleges to educate intelligent and talented Southern blacks. The question of Negro education will cause their further disagreements.

As the indirect result of Washington's politics of Negro submission to the whites, Negroes lose the right of suffrage, they become "second class" citizens inferior to the whites. Black colleges cease to be supported financially. In 1896, the Supreme Court of the USA in the case Plessy $v$. Ferguson ${ }^{4}$ upholds the constitutionality of racial segregation supporting the "separate but equal" doctrine. In 1901 Du Bois criticizes strongly the Southern discriminatory politics although at the same time he remarks that blacks must get used to such a situation. In his opinion blacks must accept segregation.

...Earn a living; get rich, and all these things shall be added unto you. Moreover, conciliate your neighbors, because they are more powerful and wealthier, and the price you must pay to earn a living in America is that of humiliation and inferiority... (Broderick, 1967, p. 71)

The path leading to economic advancement and social equality follows educating black leaders of industry and missionaries of culture who will set an example and use their knowledge to help their brothers.

...The Negro race, like all races, is going to be saved by its exceptional men... The college-bred Negro... is, as he ought to be, the group leader, the man who sets the ideals of the community where he lives, directs its thoughts and heads its social movements...(Washington et al., 2010, p. 15-25)

\section{Du Bois's Criticism of Washington's Philosophy}

Although Du Bois understands the importance of accepting economic segregation and often advocates it but only as a temporary solution of the Negro problem, he doesn't give up his belief that blacks mustn't accept their disfranchisement. Only their political action can help them improve their position. It is obvious that the ruthless Negro reality influences Du Bois's philosophy which has changed and become different from his early attitudes in the 1890s.

Du Bois becomes more critical towards black industrial schools as these schools train students for obsolete crafts and a very small number of trainees become efficient and competent workers. "...A really efficient workman must be today an intelligent man who has had good technical training in addition to thorough common school, and perhaps even higher training..." (Washington et al., 2010, p. 33) It is clear that Booker Washington and William Du Bois disagree as to the concrete solutions of the serious problems of Southern Negroes. They have completely different attitudes not only with regard to educational programs for blacks but also to their basic problem which is the right of suffrage. Both of them talk about the "leaders of industry". When mentioning them Washington actually refers to the advantages of industrial education unlike Du Bois, who stresses the importance of higher education. Because of the striking racial prejudice and discriminatory laws both leaders highlight the importance of black solidarity, especially in business.

In Du Bois's opinion Washington faces the triple paradox of his philosophy. He is striving to make Negro artisans business men and property-owners, but it is impossible for workingmen and property-owners to defend their rights without the right of suffrage. He insists on thrift and self-respect, but at the same time counsels submission to civic inferiority. He advocates common-school and industrial training, and depreciates institutions of higher learning although the majority of teachers from Tuskegee were trained in Negro colleges. ( Du Bois, n.d., p. 5) These are the reasons for the parting of the two leaders and the basis of their public confrontations. Although Washington on several occasions

\footnotetext{
4 Tammany Hall also called Tammany, the executive committee of the Democratic party in New York City historically exercising political control through the typical bossist blend of charity and patronage. When Tammany was organized in New York in 1789, it represented middle-class opposition to the power of the "aristocratic" Federalist party. Incorporated in 1805 as a benevolent body, the Society of Tammany became identified with the Democratic Party by means of identical leadership within both organizations. The society's appeal to particular ethnic and religious minorities, the doling out of gifts to the poor, and the bribing of rival political faction leaders leaders, among them the notorious "Boss" William M. Tweed, made the name Tammany Hall synonymous with urban political corruption. (Wiles, http://g00.gl/kgdt0 14.05. 2013.)
} 
openly condemns the cases of lynching blacks and stresses the significance of political rights, he also mentions some dangerous half-truths, as for example, he justifies the Southern whites for their behaviour because of the low level of civilization among blacks, and passes the responsibility for the Negro advancement in Southern society on the very blacks as they are allegedly "guilty" themselves of their position. According to Du Bois this part of Washington's doctrine reflects his weakness and has a counter-productive effect in solving the Negro question, as Washington's propaganda undoubtedly speeded up the Southern Negro disfranchisement and to an extent gave rise to more pronounced segregation as well as the withdrawal of financial aid to black colleges. The fact that industrial schools gained such a popularity at the expense of black colleges irritates Du Bois who warns about the narrow-sightedness of this practice because the isolated black community needs black leadership, i. e., college-bred leaders of industry and scholars who will help black population progress economically and culturally and who have an insight into the Negro problem from a broader perspective. ( Du Bois, 1910, p. 99)

\section{The Split between Booker Washington and William Du Bois}

The main reason of the split between the two black leaders is Du Bois's advocating open protest against injustice in society and critics towards abating any, even the slightest opposition to Washington's politics. William Du Bois and other black intellectuals like Monroe Trotter, Kelly Miller and J. W. E. Bowen are embiterred because of Washington's racial politics leaving Negroes at the mercy of the whites. They feel responsibility towards the masses of poor and ignorant Southern blacks so they openly confront Booker Washington by affirming a political strategy quite different from Washington's politics: active, persistent, organized and constant protest of blacks against white oppression and discrimination. The opposition to Washington's politics becomes more articulated especially in 1901 when black intellectuals, Monroe Trotter and George Forbes start publishing the Guardian, the magazine read by Negroes throughout America. To save his reputation of an unerring black leader Washington, in 1902 launches Boston's Advocate, and in 1903 Colored Citizen employing a large number of talented journalists who manage to deal with Washington's critics in the Guardian. In this polemic Washington's political power grows, the "Tuskegee Machine"gets stronger and becomes established even more in the American educational system thanks to the financial aid of Norhern philantropists as well as the Southern whites' support. Washington's racial philosophy fits perfectly into the plan of Northern businessmen lobbying for his prestige and power among blacks. They were convinced that with their support of Washington and his "Tuskegee Machine" they will suppress the black intelligence and prevent the emancipation of black workers.

\section{Du Bois's Radical Political Program}

In 1905 William Du Bois sends a call to a few selected persons "...for organized determination and aggressive action on the part of men who believe in Negro freedom and growth..." Then he organizes a Negro conference to "...oppose firmly present methods of strangling honest criticism; to organize intelligent and honest Negroes; and to support organs of news and public opinion."( Du Bois, 1968, p. 248) In January 1906 the Niagara Movement is founded. The program of the Movement is: freedom of speech and criticism, unsubsidizied press, manhood suffrage, the abolition of all caste distinctions based on race and colour, the recognition of the principle of human brotherhood, applying laws equally to both whites and blacks, the recognition of the highest and best human training as the monopoly of no class or race, a belief in the dignity of labour and united effort to realize these ideals under intelligent and courageous leadership. In spite of the open and courageous protest of its members, the Niagara Movement didn't weaken the power of Booker Washington. Nevertheless, due to the pressure of black radicals, Washington, on several occasions, advocated the Negro rights openly and determinedly which wasn't typical of him at all. (Broderick, 1967, p. 88) In 1904. Washington openly condemned lynching Negroes:

\footnotetext{
...three members of my race have been burned at the stake; one of them was a woman. No one ... was charged with any crime even remotely connected with the abuse of a white woman ... The custom of burning human beings has become so common as scarcely to excite interest... (Meier, 1964, p. 109)
}

The Niagara Movement didn't exist long, mainly because of disagreements among its most influential members. Similar Negro organizations, like the African-American Council and the American Black Academy rivalled the Movement whose leadership didn't manage to integrate them. The radical program of the Niagara Movement also influenced the decrease of the number of its members. Du Bois, in 1910, becomes a member of NAACP ( National Association for the 
Advancement of Colored People). NAACP is a coalition of Washington's critics from the Niagara Movement and different groups of whites advocating the rights of any individual regardless of his race or religious affiliation. Du Bois, due to his long-term experience in advocating protest and his academic background, becomes the ideal candidate for the post of the main editor of the Crisis magazine launched by NAACP. NAACP is focused on fighting Negro discrimination in society and especially their segregation. The methods suggested by the Association are education, legal fights and organized actions. It also appeals to courts and legislative bodies so that they help remove the barriers hindering Negro progress. Moreover, NAACP strives to mobilize all progressive parts of American society increasing public awareness that the problem of black segregation is the problem of each civilized American. In his first editorial Du Bois presents his vision of solving the racial problem:

\begin{abstract}
...Catholicity and tolerance, reason and forbearance can to-day make the world-old dream of human brotherhood approach realization; while bigotry and prejudice, emphasized race consciousness and force can repeat the awful history of the contact of nations and groups in the past. We strive for this higher and broader vision of Peace and Good Will... (Du Bois, 1910, p. 10)
\end{abstract}

Although the main goal of NAACP is the progress of all humans and the removal of obstacles hindering the progress of any individual, regardless of his skin colour, Du Bois, unlike the other members of the Association, fights for blacks and naturally doesn't believe the whites. He claims that Negroes must channel their physical strength, intelligence and spiritual ideals within the black population only if they want to contribute to general welfare. With such an attitude Du Bois declares himself a racist. He doesn't agree to the equal representation of whites in the struggle for human rights and democracy and excludes them from the Negro struggle.

\title{
8. Du Bois's Radicalism
}

During the second decade of the 20th century Du Bois appeals to truth and the conscience of Americans through his editorials on Negro reality. The position of Negroes in the USA is characterized by their disfranchisement, social segregation and a very great number of Negro lynchings. He comments on it and with a strong ironic note he says that "...This is the real tragedy of the Negro in America: the inner degradation,...the sort of upturning of all values which leads some black men to "rejoice" because "only" sixty-four Negroes were lynched in the year of our Lord 1912..."(Du Bois, 1913, p. 291) Malcolm X agrees with Du Bois claiming that "...The black man in North America was mentally sick in his sheeplike acceptance of the white man's culture... for centuries he had accepted the white man's Christianity-which asked the black so-called Christian...to endure the cruelties of the white so-called Christians..." (Haley, 1973, p. 319-320) Malcolm remembers the blacks from Roxbury (neighborhood in Boston) who behaved differently from the majority of blacks. They felt superior to the blacks from the ghetto. They lived in nice houses with mowed yards. These Negroes walked along the sidewalks looking haughty and dignified, on their way to work. But they were a city version of those "successful" Negro bootblacks and janitors back in Lansing. The only difference was that the ones in Boston were more anti-Negro in their behaviour. They prided themselves on being incomparably more "cultured", "cultivated" and better-off than the blacks in the ghetto. In order to be "better" than other blacks, they tried to imitate whites. Foreign diplomats could have modeled their conduct on the way the Negro postmen, Pullman porters and dining car waiters of Roxbury acted. Eight out of ten of Negroes of Roxbury worked as menials and servants who didn't want to say what their job was. They would say they worked in banking or in securities which were impressive-sounding job titles to many blacks, but the reality was that they worked as bank janitors or bond-house messengers. Malcolm could never understand why such a huge number of blacks humiliated and deceived themselves although in his youth he imitated whites as well. After he had straightened his hair he was happy because he looked like a white man, but soon he became aware of his own voluntary degradation.

\footnotetext{
...This was my first really big step toward self-degradation: when I endured all of that pain, literally burning my flesh to have it look like a white man's hair. I had joined that multitude of Negro men and women in America who are brainwashed into believing that the black people are "inferior"- and white people "superior"- that they will even violate and mutilate their God-created bodies to try to look "pretty" by white standards... (Haley, 1973, p. 56-57)
}

The author of The Color Purple introduces a different character, the proud Negro woman Sofia who dares to confront a white because of which she is pronounced guilty even without a trial and ends up in jail. The author of the novel talks about her arrival in town together with her children and friend and her fatal encounter with the mayor and his wife who asked her to be her servant. Sofia refused and the mayor slapped her. Sofia knocked him down. The police 
came and as she started to fight they injured her badly. "...Sofia really start to fight...They crack her skull, they crack her ribs. They tear her nose loose on one side. They blind her in one eye..." (Walker, 1986, p. 76-77) Sofia is only one of those proud and strong individuals who are very aware of social segregation and face it corageously. Just like tragic female characters from Greek tragedies she sacrifices herself to confirm her own system of values. These situations and persons like Sofia are the driving force of Du Bois's action. In a moment of his life, when he makes a compromise, the faiths of many Sofias were surely his fountain of power and the driving force for further action.

Claudia, the proud girl from Morrison's novel The Bluest Eye differs from other black girls as she doesn't accept the white standards of beauty.

...The big, the special, the loving gift was always a big, blue-eyed Baby Doll...Adults, older girls, shops, magazines, newspapers, window signs-all the world had agreed that a blue-eyed, yellow-haired, pink-skinned doll was what every girl child treasured...I destroyed white baby dolls. But the dismembering of dolls was not the true horror. The truly horrifying thing was The transference of the same impulses to little white girls... (Morrison, 2007, p. 13-15)

Claudia's feelings are a natural reaction to the question every man asks at a certain moment in his life: "Am I not free to develop my own qualities and live worthily?" Degraded and endangered individuals as well as social classes naturally revolt and transform their frustration into an armed resistance. After Negro lynchings in Coatesville, Pennsylvania, in 1911, Du Bois threatens openly: "... If we are to die...let us perish like men and not like bales of hay..." (Du Bois, 1911, p. 195) Malcolm X agrees with Du Bois. "....when the law fails to protect Negroes from whites' attack, then Negroes should use arms to defend themselves...I believe it's a crime for anyone who is being brutalized to continue to accept that brutality without doing something to defend himself..." (Haley, 1973, p. 373-374) In Du Bois's opinion lynching of blacks in the American South will stop when blacks start to defend themselves even at the expense of their lives. He claims that no nation gained freedom without using arms. Regarding this Du Bois's and Washington's attitudes differ completely and neither of them gave up their beliefs even then when they were close to each other in political activities, i. e., in the politics of voluntary economic segregation.

\section{The Decline of Washington's Political Strategy and His Loss of Power}

Black migrations change the picture of American towns. Negroes become numerously a respectable part of the population not only of Southern rural areas but also of Northern towns. They are not the ethnic group from Washington's beginnings any more. There are visible signs of their social, political and democratic maturity, which is testified in widespread black media. The black media will play an important role in raising Negro consciousness since a relevant number of blacks is in the system of education, and some of them have academic titles. The fact that blacks start accepting, slowly but persistently, more progressive and more radical ideas of the solution to their problem, proves their political and social maturity. The changing life conditions of blacks decrease Washington's power among the black population while Du Bois's prestige grows. Du Bois, after travelling to the American West, across 30 American states says that urban blacks are "...alive with a new ambition and determinedness...I thanked God for this kindliest race on His green earth, for whom I had the privilege of working and to whom I had the pride of belonging..." (Du Bois, 1913, p. 131132) At that time Wahington's position among blacks changes. His power is at a peak in 1912 but begins to decline when his friends are deprived of their positions in the US government. He also loses his influence among white philantropists. However, a few years before his death Washington openly criticizes the whites for their discrimination of blacks which is regarded as a significant change of his politics. He comments the Supreme Court decision according to which segregation is not unconstitutional. "...the courts in no section of the country would uphold a case where negroes sought to segregate white citizens. This is the most convincing argument that segregation is regarded as illegal..."(Harlan, 1983, p. 430) Now his rhetoric differs completely from his messages in 1895, "...we can be as separate as the fingers..." (Washington, 1986, p. 221-222) It is obvious that Washington, like Du Bois, understands the actual social and political situation in America. His political discourse is now closest to Du Bois's views. Just before his death, he gives up his accommodationist, conservative views and comes close to radicals which confirms his political realism.

\section{Du Bois's Political Pragmatism}

After 1920 Du Bois persuades Negroes to give support to Congress, state legislative bodies and senators from whom they can expect support of their programs and requirements instead of supporting presidential candidates who are not 
interested in their programs. The president might condemn lynching, but it is the senator who uses his power to open institutions such as new schools and can also ensure higher efficiency of police officers and other vital services for the black community. Negroes won't achieve much trying to influence political parties. They can improve their position only if they succeed in interesting politicians or local political bodies in their problems. With these messages Du Bois approaches the views of his bitter opponent Washington, who unfortunately isn't alive to rejoice in it. The idealist Du Bois must face reality and give up some of his ideals. He accepts the black alliance with corrupted Northern politicians as it is the only way for blacks to achieve some of their goals. Ensuring the black support to "Tammany Hall"5 in New York and "Thompson Machine"6 in Chicago Du Bois sacrificed his fragile friendship with white liberals which he had fostered because of possible political benefits for blacks. In 1928, a black candidate, Oscar DePriest was elected to Congress as the representative of the Republican party. DePriest stood for Negro causes: War Amendments, the Dyer antilynching bill, the abolition of Jim Crow in interstate commerce. "...Du Bois wished that DePriest also stood for the destruction of a political alliance with big business....and criminals,... but if DePriest had stood for virtue he would never have been elected..." (Broderick, 1967, p. 162) His example proves that a Negro can be elected to Congress only if involved in crime and with white politicians' support. In gratitude for political support, white politicians help insignificantly the growingly isolated black community.

\section{Conclusion}

From the life and political activity of Booker Washington and William Du Bois it can be concluded that both Negro leaders contributed equally to the Negro struggle for social and political equality in American society. The two black leaders complement each other; Washington, "the philosopher of the possible", uses his influence on wealthy whites in the best possible way and, in spite of racial prejudice and discriminatory laws, enables Southern Negroes industrial education thus ensuring the conditions for their survival. Washington's politics of accommodation and his advocating Negro inferiority can be understood in the context of his life circumstances: born as a slave, spends his early years in slavery, and later, after the Civil War, he attends industrial school earning high-school education. Washington believes that Southern blacks must adapt to the situation, work hard, as he did, and gradually earn their rights. The inefficiency of Washington's submissive attitude towards white aggression gives rise to the appearance of radical opposition headed by William Du Bois. Du Bois, born as a free man in the American North and educated at the most reputable universities, has a completely different vision of Negro emancipation. He insists on American Negroes having their civil and political rights immediately and advocates organized, constant political protest which culminates in the March on Washington in 1963. In 1964 the American Congress passes the Civil Rights Act ensuring at least formally political and social Negro equality.

The contribution of Booker Washington to the Negro struggle was indisputable, nevertheless radical, persistent, organized and public political pressure was crucial to achieve social and political Negro equality. More precisely, Du Bois's political program, from a historical point of view, changed radically the social position of the American Negro and made him equal to the white man. The fact that US citizens, for the first time in the history of American democracy, elected a black man President confirms this thesis.

Nevertheless both leaders confirmed a universal truth; each program which basically stems from the same vision invariably helps in the realisation of the vision. Washington sets the basis for the vision, and Du Bois its future. The two leaders parted and came close to each other, each of them denying the merits of the other, but in the end they built together a firm foundation of the future struggle for Negro emancipation.

\section{References}

Broderick, F. L. (1967). W. E. B. Du Bois, negro leader in a time of crisis. Stanford, CA: Stanford University Press.

Du Bois, W. E.B. (1903). The Souls of black folk. http://goo.gl/t42XD (20.05.2013.)

Du Bois, W. E. B. (1910). The College-bred negro American. The Atlanta University Publications, No. 15. http://goo.gl/bJFh4 (01. 06.

\footnotetext{
${ }^{5}$ The term Thompson Machine refers to urban political machiness, built largely on the votes of diverse immigrant population, dispensed jobs and assorted welfare benefits while offering avenues of social mobility at a time when local governments provided a paucity of such services. In 19th and early 20th centuries, Chicago sustained a strong two-party tradition that prevented the development of a centralized political machine. Neither the Democrats nor the Republicans succeeded in consolidating power citywide. Republicans prevailed most often in national elections; the Democrats won the majority of local contests and both parties experienced considerable divisiveness that prevented any faction from establishing hegemony. (Encyclopedia of Chicago, http://g00.gl/gGTOC 14.05.2013.)

${ }^{6} \mathrm{http}: / /$ europa.eu/legislation_summaries/enlargement/western_balkans/r18011_en.htm
} 
2013.)

Du Bois, W. E. B. (1910). The Crisis, Editorial. http://goo.gl/vVGY0 (07.05.2013.)

Du Bois, W. E. B. (1911). The Crisis, Editorial. http://goo.gl/Ytjf5 (08. 05. 2013.)

Du Bois, W. E. B. (1913). The Crisis, Editorial. http://goo.gl/RUOY5 (07.05.2013.)

Du Bois, W. E. B. (1913). The Crisis, Editorial. http://goo.gl/Z9z1s (10. 05.2013.)

Du Bois, W. E. B. (1968). The Autobiography of W. E. B. Du Bois. US: International Publishers.

Du Bois, W. E. B. (1992). Black reconstruction in America 1860-1880. New York, NY: Macmillan Publishing Company.

Encyclopedia of Chicago. Machine politics. http://goo.gl/gGTOC (14.05.2013.)

Haley, A. (1999). The Autobiography of Malcolm X. New York, NY: Ballantine Books.

Harlan, L. R. (1983). Booker T. Washington the wizard of Tuskegee, 1901-1915, Oxford, NY: Oxford University Press.

Meier, A. (1964). Negro thought in America, 1880-1915: Racial ideologies in the age of Booker T. Washington. Ann Arbor, Ml: The University of Michigan Press.

Morrison, T. (2007). The Bluest eye. London, UK: Vintage Books.

Norton, M. B., Katzman D. M., Blight D. W., Chudacoff H. P., Logevall F., Bailey B., ... Tuttle W. M. Jr. (2005). A People and a nation: A History of the United State, (7th ed.). Boston, MA: Houghton Mifflin Company.

Walker, A. (1986). The Color purple. London, UK: The Women's Press.

Washington, B. T. (1986). Up from slavery. New York, NY: Penguin Books.

Washington, B. T., Du Bois, W. E. B., Chesnutt, C. W., Smith, W. H., Kealing H. T., Dunbar P. L. \& Fortune T. T. (2010). The Negro problem. Lexington, $\mathrm{KY}$.

Wiles, D. "Boss Tweed" and the Tammany Hall Machine. http://goo.gl/kgdt0 (14.05. 2013.)

Woodward, C. V. (1974). The Strange career of Jim Crow. New York, NY: Oxford University Press. 